\title{
Impact of the expanded examination of fetal heart to the prenatal diagnosis of congenital heart diseases
}

\section{Genişletilmiş fetal kardiyak değerlendirmenin konjenital kalp hastalıklarinin prenatal tanisina etkisi}

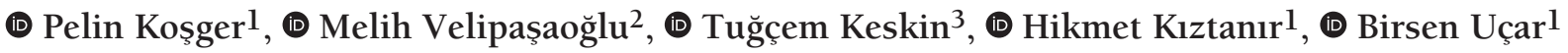 \\ ${ }^{1}$ Eskişehir Osmangazi University Faculty of Medicine, Department of Pediatric Cardiology, Eskişehir, Turkey \\ 2Eskişehir Osmangazi University Faculty of Medicine, Department of Obstetrics and Gynecology, Perinatology Unit, Eskişehir, Turkey \\ Eskişehir State Hospital, Clinic of Pediatric Cardiology, Eskişehir, Turkey
}

\begin{abstract}
Objective: In the present study, for which reasons fetal cardiac evaluation was requested from our pediatric cardiology clinic, the effects of routine fetal cardiac evaluation in obstetric ultrasonography (USG) on the detection of congenital heart disease (CHD) and the distribution of intrauterine diagnosis of CHD according to pregnancy risk profiles were retrospectively analyzed.

Materials and Methods: Fetal echocardiography reports which containing the nineteen-month period were retrospectively examined. We performed a fetal echocardiography for all pregnant women who were referred to pediatric cardiology clinic after detail obstetric USG screening. The pregnancies were categorized into two groups based on the risk of CHD: Low-risk and high-risk groups. Detected congenital cardiac structural malformations were classified as complex, moderate, and mild according to perinatal mortality risk.

Results: Of the 736 pregnancies, 22 were twin, and fetal cardiac evaluation was performed in 758 fetuses. There were 341 (46.3\%) pregnancies in the highrisk group and 395 (53.6\%) pregnancies in the low-risk group. The most common reason for fetal cardiac evaluation request was inability to adequately visualize the fetal heart (36.1\%), while suspected fetal cardiac abnormality was the second most common cause (21.3\%). Number of fetuses detected with cardiac abnormalities was 80 (23.5\%) among high-risk pregnancies, and 20 (5\%) among low-risk pregnancies. The most common type of malformation was simple cardiac abnormalities (6\%) followed by complex lesions (4.1\%). The most common cardiac abnormality was ventricular septal defect comprised of 18 cases (2.4\%) while the most common complex cardiac abnormality was pulmonary atresia (1.2\%). The rate of consistency was $40.1 \%$ between obstetricians and pediatric cardiologist in terms of the diagnosis of the congenital cardiac malformations.

Conclusion: Routine evaluation of the fetal heart by means of obstetric USG, including four chambers, outflow tracts' and three vessel views, would allow for diagnosing congenital cardiac malformations to a large extent during the intrauterine period.

Keywords: Congenital heart disease, fetal echocardiography, high risk pregnancy, low risk pregnancy, prenatal diagnosis
\end{abstract}

Öz

Amaç: Bu çalışmada pediatrik kardiyoloji kliniğimizden fetal kardiyak değerlendirmenin hangi nedenler ile talep edildiği, obstetrik ultrasonografide (USG) rutin fetal kardiyak değerlendirmenin konjenital kalp hastalıklarının (KKH) fetal ekokardiyografi ile tespitine etkisi ve intrauterine tanı koyulan KKH'nin gebelik risk profiline göre dağılımı retrospektif olarak incelenmiştir.

Gereç ve Yöntemler: On dokuz aylık döneme ait fetal ekokardiyografi raporları retrospektif olarak incelendi. Fetal ekokardiyografik değerlendirme, ayrıntılı obstetrik USG taraması sonrasında pediatrik kardiyoloji kliniğine yönlendirilen tüm gebelere yapıldı. Gebeler KKH'li fetusa sahip olma risklerine göre düşük ve yüksek riskli olarak iki gruba ayrlldı. Tespit edilen konjenital kardiyak malformasyonlar perinatal mortalite riskine göre kompleks, orta ve hafif derece olmak üzere sinıflandırıldı.

Bulgular: Toplam 736 gebenin 22 tanesi ikiz gebelik olup, 758 bebeğe fetal kardiyak değerlendirme yapıldı. Yüksek risk grubunda 341 (\%46,3), düşük risk grubunda ise 395 (\%53,6) gebelik mevcuttu. Fetal ekokardiyografik değerlendirme isteminin en sik nedeni fetal kalbin görüntülenmesinde yetersizlik $(\% 36,1)$ olup, fetal kardiyak anormallik şüphesi ikinci en sık nedendi $(\% 21,3)$. Kardiyak anomali saptanan fetus sayısı yüksek riskli gebelerde 80 (\%23,5), düşük riskli gebelerde 20 (\%5) idi. En yüksek oranda saptanan malformasyon tipi hafif kardiyak anomaliler olup (\%6), kompleks lezyon saptanma oranı ikinci sıradaydı $(\% 4,1)$. En sı saptanan kardiyak anomali ventriküler septal defekt $18(\% 2,4)$ olup, en sik saptanan kompleks kardiyak anomali ise

PRECIS: The expanded examination of the fetal heart by means of obstetric USG increases the rate of prenatal detection of congenital heart defects.

Address for Correspondence/Yazıșma Adresi: Pelin Koșger Asst Prof,

Eskişehir Osmangazi University Faculty of Medicine, Department of Pediatric Cardiology, Eskişehir, Turkey

Phone: +90 2222392979 E-mail: pelinkosger@gmail.com ORCID ID: orcid.org/0000-0002-3926-9002

Received/Geliș Tarihi: 24.03.2020 Accepted/Kabul Tarihi: 27.06.2020

${ }^{\oplus}$ Copyright 2020 by Turkish Society of Obstetrics and Gynecology

Turkish Journal of Obstetrics and Gynecology published by Galenos Publishing House 
pulmoner atreziydi (\%1,2). KKH'nin tanınması açısından obstetrisyen ve pediatrik kardiyoloji arasındaki uyum oranı \%40,1 idi.

Sonuç: Fetal kalbin dört boşluk, ventriküllerin çıkım yolları ve üç damar kesiti rutin kapsayacak şekilde obstetrik USG sırasında değerlendirilmesi, konjenital kardiyak malformasyonların intrauterin dönemde büyük oranda tanı almasına imkan sağlayabilir.

Anahtar Kelimeler: Konjenital kalp hastalıkları, fetal ekokardiyografi, yüksek riskli gebelik, düşük riskli gebelik, prenatal tanı

\section{Introduction}

Congenital heart disease (CHD) is the most common congenital abnormality, and it is six times more common than chromosomal abnormalities and four times more common than neural tube defect ${ }^{(1)}$. The incidence of CHD is 8-10 cases per 1000 live births (0.8\%-1\%) for full-term births, and this rate is approximately 10 times more (8.3\%) for preterm births ${ }^{(2)}$. Approximately 17\%-33\% of CHDs include critical malformations, which must be intervened directly after birth and/or just before birth. Unfortunately, 50\% of these malformations are diagnosed after the infant is discharged from the hospital, and the mortality risk increases because of the delay. The identification of severe cardiac abnormalities during the intrauterine period enables the use of approaches that lead to significant decreases in perinatal morbidity and mortality, such as performing the delivery at a center where cardiac surgery can be performed, providing the required medical support in the newborn intensive care unit until transfer to the relevant center, and/or if needed, promptly performing transcatheter palliative interventions. Therefore, fetal cardiac evaluation has become an important part of obstetric ultrasonography (USG), and fetal echocardiography evaluation requests have increased due to increased incidences of suspected CHD. Although the risks of $\mathrm{CHD}$ are defined and fetal cardiac evaluation is recommended for all high-risk pregnancies, $90 \%$ of $\mathrm{CHDs}$ are observed in lowrisk pregnancies ${ }^{(3,4)}$.

The current approach in many clinics in Turkey involves performing fetal cardiac evaluations within defined indications owing to long examination times and inadequate number of pediatric cardiologists and cardiovascular surgery experts. Our hospital is a tertiary center and includes the only perinatology and pediatric cardiology clinic that provides services to a large region, which consists of our city and neighboring cities. In the present study, for which reasons fetal cardiac evaluation was requested from our pediatric cardiology clinic, the effects of routine fetal cardiac evaluation in obstetric USG on the detection of CHDs and the distribution of intrauterine diagnosis of CHDs according to pregnancy risk profiles were retrospectively analyzed.

\section{Materials and Methods}

In this retrospective study, the total number of anomaly scans in the perinatology unit during the study period (May 2017 - January 2019) were 8372 and the number of referred pregnancies for fetal echocardiography evaluations were 736 . All patients in the study underwent routine fetal anatomic scanning according to the International Society of Ultrasound in Obstetrics and Gynecology guidelines between the $18^{\text {th }}$ and $22^{\text {nd }}$ weeks of pregnancy in the Department of Perinatology at our university. In this scan, four chambers of the heart, three vessel and trachea, left and right ventricular outflows, and the heart were examined using color Doppler USG ${ }^{(5)}$. Subsequently, the patients were referred to the Department of Pediatric Cardiology unit form perinatology division of our university hospital either suspected cardiac abnormalities, accompanying diseases that increase risk of fetal cardiac malformations, parental congenital heart malformation or suboptimal evaluation during routine anomaly scan. To identify all reasons for fetal echocardiography requests, detailed obstetric USG reports of each case were retrieved from the system and examined, and the reasons for fetal echocardiography requests were determined as accurately as possible by comparing these with our records. Pre-gestational and gestational medical data of pregnant women were retrieved. Comorbid medical problems that may be considered as risky for $\mathrm{CHD}$, medication use, and characteristics of previous pregnancies were recorded. The pregnancies were categorized into two groups based on the risk of CHD: low-risk and high-risk groups. Fetal cardiac evaluation was performed by the same single operator (P.K) in the Department of Pediatric Cardiology using a C5-1 convex probe with an Affinity 70 (Philips, WA, USA) device. In all fetal echocardiography examinations, cardiac situs, size and position, systemic and pulmonary venous connections, atrial and ventricular chambers, atrioventricular and semilunar valves, ventriculoatrial shunts, great vessels outflow tracts, ductal and aortic arches, and rhythm were evaluated. If all views could not be clearly evaluated or if a suspicious finding is detected in the first evaluation, repeated evaluations may be required. Echocardiography images and reports of each patient were recorded. Fetal echocardiographic evaluation was scheduled according to the gestational week of the pregnancy, the referral diagnosis of the fetus, and the availability of our out-patient clinic. Each case was informed about applying for postnatal cardiac evaluation even if no pathology was detected in the fetal evaluation. For the purpose of performing as many evaluations and as early as possible, postnatal echocardiography evaluations are performed without appointment in our clinic. The postnatal data of 261 infants were retrieved of 714 single and 22 sets of twins, and 758 infants in total from 736 pregnancies were examined. Prenatal and postnatal echocardiography data of 261 cases, for which postnatal data could be retrieved, were compared.

Detected congenital cardiac structural malformations were classified as complex, moderate, and mild according to perinatal mortality risk (Table 1$)^{(6,7)}$. Malformations that are not included in this classification, and malformations with low mortality risk 
Table 1. Classification of prenatally diagnosed congenital heart defects

Heterotaxy or atrial isomerism, single ventricle, hypoplastic left heart, pulmonary atresia, tricuspid atresia,

Complex; atresia or severe hypoplasia of a valve or chamber aortic atresia, mitral atresia, and Ebstein's anomaly, complet atrioventricular septal defect, truncus arteriosus, congenitally corrected transposition of the great arteries, double outlet left or right ventricle

Modere; congenital heart disease Transposition of the great vessels, tetralogy of Fallot, coarctation of the aorta, aortopulmonary window, critical aortic or pulmonary stenosis, partial atrioventricular septal defect, total anomalous pulmonary venous connection, large ventricular septal defect

Small ventricular septal defect, atrial septal defect and less severe aortic or pulmonary stenosis

Minor; no intervention

Dysrhthmias, cardiomyopathies,

Others secondary dextrocardia/levocardia and restrictive ductus

were evaluated in the others category. This study was approved by the Eskişehir Osmangazi University Institutional Ethics Committee.

\section{Statistical Analysis}

Statistical analysis was performed using Statistical Package for Social Sciences, version 15 (SPSS, Chicago, USA). The pregnancies were categorized into two groups based on the risk of CHD. The fetal echocardiography request reasons and the congenital cardiac malformation rates were classified according to pregnancy risk profile. The prevalence of CHDs in low- and high- risk pregnancies was compared using the chi-square test. Statistical significance was inferred at $\mathrm{p}<0.05$.

\section{Results}

The mean age of the mothers was $29.8 \pm 5.6$ years (range, 1747 years), and the mean gestational age at which the fetal echocardiography examination was performed was $26.4 \pm 4.4$ weeks. Of the 736 pregnancies, 22 were twin pregnancies, and fetal cardiac evaluation was performed in 758 fetuses. Twelve patients underwent examination for a second time. In total, $37.9 \%$ of the examinations were performed before the $24^{\text {th }}$ week of pregnancy, while $62.1 \%$ were performed after the $24^{\text {th }}$ week of pregnancy. Number of fetuses with congenital structural cardiac malformation was $101(13.7 \%)$, and the number of fetuses with arrhythmia was 15 (2\%).

The reasons for fetal echocardiography requests were classified according to $\mathrm{CHD}$ risk profiles considering the American Heart Association recommendations (Table 2$)^{(8)}$. The prevalence of $\mathrm{CHD}$ according to risk factors was determined. There were 341
(46.3\%) pregnancies in the high-risk group and 395 (53.6\%) pregnancies in the low-risk group. The most common cause for fetal cardiac evaluation request was inability to adequately visualize the fetal heart (36.1\%), while suspected fetal cardiac abnormality was the second most common cause (21.3\%). Fetal cardiac malformation was detected as the most frequent among pregnant women referred to the pediatric cardiology due to suboptimal evaluation during routine anomaly scan (37.5\%).

The distribution of CHDs, which were diagnosed with fetal echocardiography and classified according to mortality risk according to pregnancy risk groups was presented in Table 3. Number of fetuses detected with cardiac abnormalities was $80(23.5 \%)$ among high-risk pregnancies, and 20 (5\%) among low-risk pregnancies. The prevalence of cardiac abnormalities in each category was higher in high-risk pregnancies (Table 4). The most common type of malformation was simple cardiac abnormalities (6\%) followed by complex lesions (4.1\%). The most common cardiac abnormality was ventricular septal defect (VSD) comprised of 18 cases (2.4\%) while the most common complex cardiac abnormality was pulmonary atresia (PA) $(1.2 \%)$. The moderate cardiac abnormality was TOF including nine cases (1.2\%). Out of 20 fetuses $(2.7 \%)$ evaluated with suspected fetal cardiac arrhythmia, two had complete atrioventricular block, two fetuses had blocked premature atrial contractions, and two fetuses had supraventricular tachycardia. The other nine fetuses had premature atrial and ventricular contractions, which recovered during the late weeks of pregnancies.

The number of fetuses for which postnatal cardiac evaluation records could be retrieved via echocardiography examinations performed after birth, autopsy reports of terminated fetuses, and late period presentations to our clinic for follow-up purposes was 261 (35.4\%). Of the 261 infants, 43 (16.4\%) had CHD. As the prenatal and postnatal results were compared, there were 24 (9.1\%) discordant diagnoses: One major and 23 minor. In one fetus for which fetal echocardiography was requested because of the presence of a sibling with heart disease and which did not have fetal cardiac abnormalities, total anomalous pulmonary venous return was detected in the first postnatal week. Twentythree minor discordant diagnoses [15 atrial septal defect (ASD)], 4 VSD, 1 bicuspid aortic valve, 3 pulmonary stenosis] belonged to the class of simple heart diseases.

\section{Discussion}

Diagnosis of CHD during the intrauterine period provides significant benefits as performing of the birth under appropriate conditions, mentally prepared family, defining potential genetic abnormalities, and termination of pregnancy in the presence of complex malformations. Moreover, it was reported that diagnosis of some specific CHDs during the prenatal period increases the survival rate as well ${ }^{(9)}$. However, due to long duration of fetal echocardiography and requirement of an experienced pediatric cardiologists, it is not routinely performed 
Table 2. The distribution of the fetal echocardiography request reasons and the congenital cardiac malformation rates according to pregnancy risk profile*

Indications with higher risk profile

Gestational diabetes

Pregestational diabetes

Collagen tissue disease (maternal autoantibodies)

CHD in the first degree relatives of the fetus (mother, father, siblings)

Fetal cardiac abnormality suspected on obstetrical ultrasound

Fetal extracardiac abnormality suspected on obstetrical ultrasound

Fetal tachycardia or bradycardia, or frequent or persistent irregular heart rhythm

Fetal increased NT $>95 \%(\geq 3 \mathrm{~mm})$

Monochorionic twinning

Fetal hydrops or effusions

Polyhidramnios

Total

\section{Indications with lower risk profile}

Maternal medications (anticonvulsants, NSAIDS in first/second trimester)

Fetal abnormality of the umblical cord or placenta

Abnormal first or second trimester screening tests

Oligohydramnios

Late maternal age

Suboptimal evaluation

Total

CHD: Congenital heart disease, NSAIDS: Non-steroidal anti-inflammatory drug, NT: Nuchal translucency

Total n (\%) CHD n (\%)

$30(4.1) \quad 2(6.7)$

$27(3.7) \quad 2(7.4)$

$6(0.8) \quad 1(20)$

$25(3.4) \quad 0(0)$

$157(21.3) \quad 63(40.1)$

$20(2.7) \quad 3(15)$

$20(2.7) \quad 1(5)$

$16(2.2) \quad 1(6.25)$

$22(3) \quad 3(13.6)$

13 (1.7) 2 (15.3)

$4(0.5) \quad 2(50)$

$341(46.3)$

80 (23.5)

$\begin{array}{ll}28(3.8) & 1(3.6) \\ 19(2.6) & 2(10.5) \\ 41(5.6) & 2(4.9) \\ 6(0.8) & 1(16.6) \\ 35(4.8) & 3(8.6) \\ 266(36.1) & 11(4.1) \\ 395(53.6) & 20(5)\end{array}$

in all pregnant women. Thus, basic fetal cardiac evaluation has become a part of the USG in routine obstetric monitoring. CHDs can be detected during the intrauterine period at a rate of $4.5 \%$ $8.1 \%$ with the evaluation of the fetal heart in four chamber view and at $43.8 \%-85.5 \%$ with the additional examination of the right and left ventricular outflow tracts ${ }^{(9)}$. Therefore, the prevalence of intrauterine diagnosis of $\mathrm{CHD}$ varies according to the protocol performed by the centers for fetal cardiac evaluation ${ }^{(10,11)}$. In the present study consisting of an eighteen-month period, fetal congenital cardiac malformation prevalence was $13.7 \%$. Fetal congenital cardiac malformation prevalence was reported to be $5.6 \%$ from another tertiary center in Turkey ${ }^{(12)}$. At our center, evaluation of the fetal heart in four chamber view is a routine part of the obstetric USG. Moreover, detailed fetal cardiac evaluation including right and left ventricular outflow tracts and three vessels and trachea view is routinely performed in each pregnant woman by skilled perinatologists between the $18^{\text {th }}$ and $22^{\text {nd }}$ weeks of pregnancy. Furthermore, since the fetal echocardiography was performed in selected pregnancies who were identified as risky in antenatal screening in our tertiary reference center, the reported prevalence may be higher than expected.

In the present study, while suspected fetal cardiac abnormality was the second most common (21.3\%) reason for fetal

echocardiography request, inadequate evaluation of the fetal heart was the most common reason (36.1\%). Prevalence of family history of CHD and maternal diabetes mellitus (DM), which were reported to be the top two most common reasons for fetal echocardiography requests in the previous studies, were $3.4 \%$ and $7.8 \%$, respectively in the present study ${ }^{(10,13)}$. In the present study, similar to Cha et al. ${ }^{(14)}$, detection of an abnormal cardiac finding during obstetric follow-up was more common than family history of CHD and maternal DM among the reasons for fetal echocardiography requests. Compatibility between the findings of the pediatric cardiologist and the obstetrician in the cases referred to fetal echocardiography with suspected CHD by the obstetricians varies according to the experience of the centers. In the current study, the rate of consistency was $40.1 \%$ between obstetricians and pediatric cardiologist in terms of the diagnosis of the congenital cardiac malformations. Simpson ${ }^{(15)}$ reported that cardiac malformation was detected during fetal echocardiography in 45 of 275 (16\%) pregnant women referred with suspected CHD, while Meyer-Wittkopf et al. ${ }^{(16)}$ demonstrated that cardiac abnormality was detected in 209 out of 268 (77.9\%) pregnant women referred to fetal echocardiography with suspected fetal cardiac abnormality, and the diagnosis was fully compatible in $62 \%$ of 
Table 3. Intrauterine detected congenital heart diseases and their distribution according to pregnancy risk groups*

\begin{tabular}{|c|c|c|c|}
\hline $\begin{array}{l}\text { Results of fetal } \\
\text { echocardiography }\end{array}$ & $\begin{array}{l}\text { High risk } \\
\text { group (n) }\end{array}$ & $\begin{array}{l}\text { Low risk } \\
\text { group (n) }\end{array}$ & $\begin{array}{l}\text { Total n } \\
(\%)\end{array}$ \\
\hline \multicolumn{4}{|l|}{ Complex } \\
\hline PA with IVS/VSD/AVSD & 9 & 0 & $9(1.2)$ \\
\hline Single ventricule & 2 & 0 & $2(0.3)$ \\
\hline HLHS & 6 & 0 & $6(0.8)$ \\
\hline DORV & 3 & 1 & $4(0.5)$ \\
\hline Ebstein's anomaly & 2 & 0 & $2(0.3)$ \\
\hline $\begin{array}{l}\text { Idiopatic diffuse } \\
\text { calsification }\end{array}$ & 1 & 0 & $1(0.1)$ \\
\hline Shone complex & 2 & 0 & $2(0.3)$ \\
\hline Left atrial isomerism & 2 & 0 & $2(0.3)$ \\
\hline AVSD & 2 & 0 & $2(0.3)$ \\
\hline Total & 29 & 1 & $30(4.1)$ \\
\hline \multicolumn{4}{|l|}{ Modere } \\
\hline $\mathrm{TOF}$ & 7 & 2 & $9(1.2)$ \\
\hline $\mathrm{CoA}$ & 5 & 1 & $6(0.7)$ \\
\hline d-TGA & 4 & 0 & $4(0.5)$ \\
\hline Total & 16 & 3 & $19(2.4)$ \\
\hline \multicolumn{4}{|l|}{ Simple } \\
\hline VSD & 14 & 4 & $18(2.4)$ \\
\hline Possible CoA & 4 & 3 & $7(1)$ \\
\hline PS & 0 & 3 & $3(0.4)$ \\
\hline AS & 8 & 2 & $10(1.4)$ \\
\hline ASD & 2 & 3 & $5(0.7)$ \\
\hline Total & 28 & 15 & $43(6)$ \\
\hline \multicolumn{4}{|l|}{ Other } \\
\hline Tricuspid regurgitation & 1 & 0 & $1(0.1)$ \\
\hline LPVCS & 3 & 0 & $3(0.4)$ \\
\hline Intracardiac Mass & 2 & 0 & $2(0.3)$ \\
\hline Double aortic arch & 1 & 0 & $1(0.1)$ \\
\hline Dextrocardia & 1 & 0 & $1(0.1)$ \\
\hline Dysrhythmias & 14 & 1 & $15(2)$ \\
\hline Total & 22 & 1 & $23(3)$ \\
\hline
\end{tabular}

CoA: Coarctation of aorta, AS: Aort stenosis, ASD: Atrial septal defect, AVSD: Atrio ventricular septal defect, DORV: Double outler right ventricle, HLHS: Hypoplastic left heart syndrome, IVS: Intact ventricular septum, LPVCS: Left persistant vena cava superior, PA: Pulmonary atresia, PS: Pulmonary stenosis, TGA: Transposition of great vessels, TOF: Tetralogy of Fallot; VSD: Ventricular septal defect

"The prevalence of cardiac abnormalities in each category was higher in high-risk pregnancies. According to the chi-square test, $\mathrm{p}<0.001$

these patients. Obstetricians' increasing experience in evaluating fetal heart enables us to diagnose a higher rate of CHD during the intrauterine period.

When pregnant women that underwent fetal echocardiography were classified according to risk levels in terms of fetal cardiac
Table 4. Comparison of pregnancy risk groups in terms of fetal echocardiography results

\begin{tabular}{l|l|l|l}
$\begin{array}{l}\text { Fetal cardiac } \\
\text { anomaly }\end{array}$ & $\begin{array}{l}\text { High risk group } \\
\mathrm{n}(\%)\end{array}$ & $\begin{array}{l}\text { Low risk group } \\
\mathrm{n}(\%)\end{array}$ & $\mathrm{p}^{*}$ \\
\hline $\begin{array}{l}\text { Complex } \\
\text { Modere }\end{array}$ & $29(8.5)$ & $1(0.25)$ & \\
Simple & $16(4.7)$ & $3(0.9)$ & \\
Other & $28(8.4)$ & $16(4.2)$ & $<0.001$ \\
\hline
\end{tabular}

*chi-square test

malformation; $46.3 \%$ were in the high-risk group, and 53.6\% were in the low-risk group. In fetal echocardiography, CHD was detected most commonly in the high-risk group with a rate of $23.5 \%$. In the low-risk group, determination of congenital heart abnormality rate was $5 \%$, and it was significantly higher among high-risk pregnancies. This was associated with the detection of cardiac malformation in $40.1 \%$ of pregnancies referred to fetal echocardiography due to suspected fetal cardiac malformation in the obstetric USG. In the study of Nayak et al. ${ }^{(9)}$, in which fetal echocardiography was performed in all pregnant women over a period of 4 years, they highlighted the importance of fetal echocardiography. They concluded that the fetal echocardiography should be included as a part of routine antenatal screening irrespective of risk factors for CHD. According to the their results, the prevalence of prenatal CHD was similar between high- and low-risk pregnancies, but the majority of pregnancies with cardiac malformation was in the low-risk group ${ }^{(9)}$, which is contrary to our finding. Operator misevaluation, failure to notice cardiac malformation, and inadequacy of and failure to interpret fetal cardiac image views were given as the reasons for failure to detect complexstructured fetal cardiac malformations in obstetric USG. The missing diagnoses in these pregnancies, which were referred with low-risk, were made with fetal echocardiography ${ }^{(9)}$. Evaluation of fetal heart in obstetric USG requires experience and knowledge, and obstetric fetal cardiac evaluation which is not optimally performed owing to various reasons can cause complex cardiac malformations to be missed. Therefore, we find it appropriate to refer these pregnant women in whom fetal heart could not be adequately evaluated by obstetric USG with reasons similar to those stated by Nayak et al. ${ }^{(9)}$ to fetal echocardiography in our center as well. According to our results, inadequate evaluation of fetal heart in obstetric USG is the most common (31\%) reason for requesting fetal echocardiography. However, fetal cardiac malformation was detected only in $4.1 \%$. This was associated to a large extent with high-risk pregnancies in which obstetric fetal cardiac evaluation was conducted by an experienced perinatologist.

It is known that the prevalence of CHD differs during the intrauterine and postnatal periods. Isolated VSD is the most common CHD during the postnatal period, which is also reported to be the most common CHD diagnosed during the 
intrauterine period as well ${ }^{(12,17)}$. In the present study, consistent with the literature, the most common cardiac malformation in fetal echocardiography is VSD. In the previous studies, complex cardiac malformations were reported to be the most common group of $\mathrm{CHD}^{(9,12,18)}$. However, we found complex cardiac malformations as the second most common following minor lesions. It was considered that this variation may be related to some differences in the classification of cardiac lesions between the studies. Moreover, in the present study, consideration of the higher but insignificant increases in flow velocities at semilunar valves may have played a role in the increased number of minor lesions. In previous studies, atrioventricular septal defect (AVSD) and hypoplastic left heart syndrome (HLHS) were reported to be complex cardiac lesions that are detected at a similar or higher prevalence ${ }^{(12,18,19)}$. In the present study, the most common complex CHD was PA, followed by HLHS.

Since the pregnancies diagnosed with complex type congenital cardiac malformations were referred to the surgical center during the prenatal or postnatal period, and the others diagnosed as moderate type lesions gave birth in our hospital, postnatal results of all of these pregnancies were retrieved. Moreover, most of the 261 (35.4\%) cases, whose postnatal echocardiography results could be retrieved, were diagnosed with fetal cardiac abnormality by an obstetrician or pediatric cardiologist. The incompatibility between prenatal and postnatal echocardiography in these 261 cases were mostly due to simple lesions. It was found that the diagnoses did not change in complex lesions which were detected by a pediatric cardiologist, but one case with a normal fetal echocardiography was diagnosed with total anomalous pulmonary venous return abnormality during the postnatal period. Pulmonary venous return abnormalities, small or moderate sized ventricular or ASD, and minor valve lesions cannot always be defined with fetal echocardiography, and are frequently diagnosed after birth $^{(8)}$. Meyer-Wittkopf et al. ${ }^{(16)}$ also reported that a total anomalous pulmonary venous return abnormality diagnosed in the postnatal period could not be detected in the fetal echocardiography.

\section{Study Limitations}

Although each evaluated pregnant woman was informed about the importance of postnatal echocardiography, a significant amount of postnatal echocardiographic evaluation, in which a statistical analysis for sensitivity and specificity could not be performed in order to make a confirmation or comparison.

\section{Conclusion}

In many centers, regardless of CHD risk, it is still not possible to perform fetal echocardiography by a pediatric cardiologist to all pregnant women. Therefore, routine evaluation of the fetal heart by means of obstetric USG, including four chambers, outflow tracts' and three vessel views, would allow for diagnosing congenital cardiac malformations to a large extent during the intrauterine period.

\section{Ethics}

Ethics Committee Approval: This study was approved by the Eskişehir Osmangazi University Institutional Ethics Committee (approval no: 25403353-050.99).

Informed Consent: The study is retrospective.

Peer-review: Externally and internally peer-reviewed.

\section{Authorship Contributions}

Surgical and Medical Practices: P.K., T.K., H.K., M.V., B.U., Concept: P.K., M.V., B.U. Design: P.K., M.V., B.U., Data Collection or Processing: P.K, T.K., H.K., M.V., Analysis or Interpretation: P.K, T.K., H.K., M.V., B.U., Literature Search: P.K., M.V., Writing: P.K., M.V.

Conflict of Interest: The authors report no conflict of interest. Financial Disclosure: Authors have no financial interests about the research.

\section{References}

1. Midan MF, Alsheemy RI, Eid SM, Abdel Salam ME. Efficacy of fetal echocardiography in prenatal diagnosis of congenital heart diseases. Int J Reprod Contracept Obstet Gynecol 2016;5:1553-7.

2. Bravo-Valenzuela NJ, Peixoto AB, Araujo Júnior E. Prenatal diagnosis of congenital heart disease: A review of current knowledge. Indian Heart J 2018; 70:150-64.

3. Levi S. Ultrasound in prenatal diagnosis: polemics around routine ultrasound screening for second trimester foetal mal-formations. Prenat Diagn 2002;22:285-95.

4. Sainz JA, Zurita MJ, Guillen I, Borrero C, García-Mejido J, Almeida $\mathrm{C}$, et al. Prenatal screening of congenital heart defects in population at low risk of congenital defects. A reality today. An Pediatr (Barc) 2015;82:27-34.

5. International Society of Ultrasound in Obstetrics and Gynecology, Carvalho JS, Allan LD, Chaoui R, Copel JA, DeVore GR, et al. ISUOG Practice Guidelines (updated): sonographic screening examination of the fetal heart. Ultrasound Obstet Gynecol 2013;41:348-59.

6. Dolk H, Loane M, Garne E, European Surveillance of Congenital Anomalies (EUROCAT) Working Group. Congenital heart defects in Europe: prevalence and perinatal mortality, 2000 to 2005. Circulation 2011;123:841-9.

7. Slodki M, Respondek-Liberska M. New classifications of prenatally diagnosed congenital heart defects and their influence on neonatal survivability. Prenat Cardio 2015;5:6-8.

8. Donofrio MT, Moon-Grady AJ, Hornberger LK, Copel JA, Sklansky MS, Abuhamad A, et al. Diagnosis and treatment of fetal cardiac disease: a scientific statement from the American Heart Association. Circulation 2014;129:2183-242.

9. Nayak K, Chandra GS, Shetty R, Narayan PK. Evaluation of fetal echocardiography as a routine antenatal screening tool for detection of congenital heart disase. Cardiovasc Diagn Ther 2016;6:44-9.

10. Zhang YF, Zeng XL, Zhao EF, Lu HW. Diagnostic Value of Fetal Echocardiography for Congenital Heart Disease: A Systematic Review and Meta-Analysis. Medicine (Baltimore) 2015;94:e1759.

11. Ren YY, Li XT, Gui YH, Yan YL, Chang C, Zhang JH, et al. Evaluation of the prenatal screening mode for fetal congenital heart diseases by ultrasound. Zhonghua Fu Chan Ke Za Zhi 2008;43:589-92.

12. Ozbarlas N, Erdem S, Küçükosmanoglu O, Sevdaoglu G, Demir $\mathrm{C}$, Evrüke $\mathrm{C}$, et al. Prevalence and distribution of structural heart 
diseases in high and low risk pregnancies. Anadolu Kardiol Derg 2011;11:125-30.

13. Friedberg MK, Silverman NH. Changing indications for fetal echocardiography in a University Center population. Prenat Diagn 2004;24:781-6.

14. Cha S, Kim GB, Kwon BS, Bae EJ, Noh CII, Lim HG, et al. Recent trends in indications of fetal echocardiography and postnatal outcomes in fetuses diagnosed as congenital heart disease. Korean Circ J 2012;42:839-44.

15. Simpson LL. Indications for fetal echocardiography from a tertiarycare obstetric sonography practice. J Clin Ultrasound 2004;32:1238.

16. Meyer-Wittkopf M, Cooper S, Sholler G. Correlation between fetal cardiac diagnosis by obstetric and pediatric cardiologist sonographers and comparison with postnatal findings. Ultrasound Obstet Gynecol 2001;17:392-7.

17. Sharma S, Kaur N, Kaur K, Pawar NC. Role of echocardiography in prenatal screening of congenital heart diseases and its correlation with postnatal outcome. J Clin Diagn Res 2017;11:12-4.

18. Rocha LA, Junior Araujo E, Rolo LC, Barros FS, da Silva KP, Leslie AT, et al. Prenatal detection of congenital heart diseases: One-year survey performing a screening protocol in a single reference center in Brazil. Cardiol Res Pract 2014;2014:175635.

19. Charafeddine F, Hachem A, Kibbi N, Abutaqa M, Bitar F, Bulbul $Z$, et al. The first fetal echocardiography exper,ence for prenatal diagnosis of congenital heart disease in Lebanon: Successes and challendes. J Saudi Heart Assoc 2019;31:125-9. 